\title{
Electromagnetic Pollution of the Environment and its Effects on the Materials from the Built up Media
}

\author{
IOSIF LINGVAY', ADRIANA MARIANA BORS2*, DANIEL LINGVAY3,6, LADISLAU RADERMACHER ${ }^{4}$, VLAD NEAGU5 \\ 1.National Institute for Research and Development in Electrical Engineering INCDIE ICPE-CA, 313, Splaiul Unirii, 030138, Bucharest, \\ Romania \\ 2.ICPE SA, 313, Splaiul Unirii, 030138, Bucharest, Romania \\ 3.Technical University of Cluj, Faculty of Electronics, Telecommunications and Information Technology, 26-28 George Baritiu Str., \\ 400027, Cluj Napoca, Romania \\ 4.University of Petrosani, Petrosani, Bucharest, Romania \\ 5.Technical University of Cluj, Faculty of Electrical Engineering, 26-28 Geroge Baritiu Str., 400027, Cluj Napoca, Romania \\ ${ }^{6}$ Sapientia Hungarian University of Transylvania, Faculty of Sciences and Arts, 4 Calea Turzii, 400193, Cluj Napoca, Romania
}

\begin{abstract}
In built up media (complex built environment), the materials are simultaneously exposed to a series of physical, chemical and microbiological stress factors that act synergistically with disturbing electromagnetic fields and cause material degradation - with consequences on the durability and safety in exploitation of buildings and installations. The main generative sources of disturbing fields (stray current generators) on built up media are railroads with DC or AC traction with various operating voltage and frequency, medium and high voltage overhead power lines and unbalanced currents from a three-phase power system. The generated stray currents cause destruction both in metallic elements of built structures (railroads, power installations) and in neighbouring constructions and installations (belonging to other administrations) with negative environmental implications.
\end{abstract}

Keywords: corrosion, stray currents, electromagnetic pollution, built structures

With a view to sustainable development, the durability and safety of built structures (buildings and installations especially high-risk in exploitation ones such as gas and oil pipelines, power installations etc.) is a priority issue.

The durability and safe operation of buildings and installations (built up media) is determined by their degradation, ageing due to the simultaneous and synergistic action of several stress factors specific to the environment (usually complex polluted) exploitation such as chemical and microbiological soil aggressiveness, aggressive pollutants from the atmosphere $\left(\mathrm{SO}_{2}, \mathrm{H}_{2} \mathrm{~S}, \mathrm{CO}_{2}\right.$ etc.), mechanical stresses, ionizing and non-ionizing radiation and, last but not least, electrical stresses [1].

By their specificity, electrical disturbances can be either, functional electromagnetic pollution of environment $[1,2]$ ) (e.g. of an anthropogenic origin operating voltage of power cables) or of a natural origin (telluric currents, atmospheric discharge - lightning). Intelligent and predictive diagnosis studies can evaluate the degradation state of targets, the appointmentand timing of repairs and the safe exploitation lifetime of built-up media objectives. These studies achievement presupposes the stressors factors knowledge (intensity, mechanism and kinetics of the degradation processes caused, synergy effects, etc.) acting on the investigated objectives [3-7].

The paper aim is to analyze the degradation induced by the environmental electromagnetic pollution effects on the builtmedia.

\section{Electromagnetic pollution sources- stray current generating voltage}

Soil, natural environment, electro-conducting medium, of $2^{\text {nd }}$ order electrolytic [1] conductors, where there are numerous metallic structures exposed to corrosion, is a heterogeneous environment, being a relatively weak electric conductor and heaving an electrical resistivity of between 1 and $1000 \Omega \mathrm{m}$. On the other hand, concrete - a material often used in construction - is also a heterogeneous environment, which, depending on the actual operating conditions, can become a $2^{\text {nd }}$ order electrolytic conductor with an electrical resistivity below $1000 \Omega \mathrm{m}$ [8]. The voltage difference applied to these electrolytic environments generate current lines focused on preferential high conductivity paths, the shortest current path - respectively on the metallic structures in these environments (underground metallic pipes, steel reinforcements of structures reinforced concrete etc.), which have a resistivity below 10-6 $\Omega \mathrm{m}$. Under these conditions the currents cross at least twice the metal / electrolyte interface - with all the related consequences on the corrosion reactions kinetics.

The source of all disturbing electrical signals of the natural electrochemical processes is the chain of generation / transmission / distribution and electric energy use $[1,2]$.

The perturbing voltage is primarily the $\mathrm{AC}$ alternating current with a power frequency overlapping both the harmonics and the transients generated by the power system and the reactive consumers and / or those operating in switching mode [9-12] as well as the DC components from industrial consumers such as electric traction in DC (tram, subway, etc.) and / or industrial installations in DC (such as electrolysers) [1].

Under these conditions, stray currents generated are complexes and contain both DC components and AC components in a wide spectrum of frequencies.

The following are some representative situations where metallic structures are disturbed by DC and / or AC stray currents.

In figure 1 is a simplified circuit diagram of AC disturbances due to three phase power system imbalance currents.

By analyzing the diagram of figure 1 it's found that $A C$ stray current by pipeline IAC is component of unbalanced current IU [13], respective (1):

$$
I_{U}=I_{A C}+I_{U S}
$$

*email: adrianambors@gmail.com; Phone: 0773917319 
In (1) the $I_{A C} / I_{U S}$ ratio is determined by the insulation level between the pipeline and the ground, the ground resistivity, the distance between the grounding plugs and the pipeline geometric position to the grounding plugs. It's

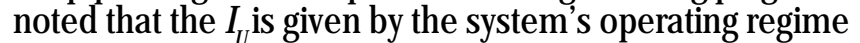
and does not depend on how to execution (overhead or underground) power lines.

In the overhead power lines case, the pipeline is disturbed in addition to $I_{A C}(1)$ by a induced current computable by long conductor and / or long conductor methods (based on Maxwell's equations where resolutions are made using different methods of numerical analysis more often the finite elements method) [14-17].

Similarly, AC stray currents are generated in steel rebar from underground reinforced concrete structures.

In figure 2 the complex $\mathrm{AC}$ disturbances coming from overhead power lines and electrified railroads are presented.

Analyzing the depiction from figure 1 it is noted that the $I_{\text { }}$ component decrease may be achieved by increasing the insulation level between the railroad and soil as well as between the perturbed metallic structure and soil (electroinsulating layers applied on the pipes [19-21]).

Figure 1 and figure 2 show that in practice the ELF extremely low frequency (power frequency and harmonics) AC stray currents which disturbs the metallic structures operating in electro-conductive environments of II order (soil and/ or reinforced concrete) come primarily from tree phase power system by both induction and voltage drop (due to imbalances betw een phases and / or major consumers specifics such as electrified railroads).

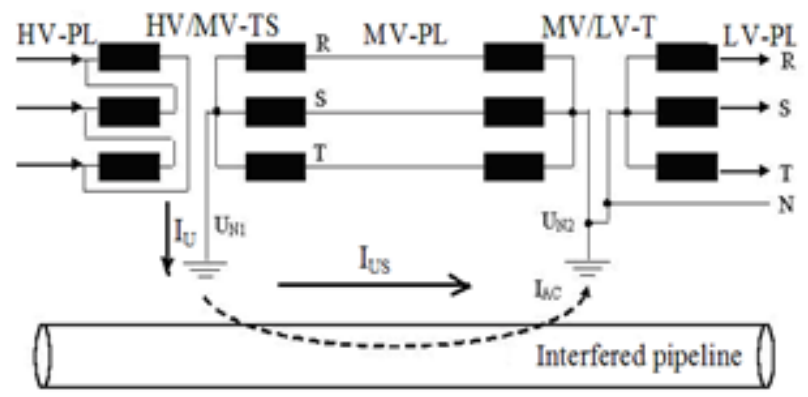

Fig. 1. Simplified layout of AC disturbances that come from the three-phase power system: HV -high voltage; PL -power line; MV -medium voltage; TS -transformer station; LV -low voltage; T -transformer; R, S, T -phase; UN1, UN1 - unbalanced voltages; $\mathrm{N}$ - physical neutral conductor; IAC -AC stray current by pipeline; IU -unbalanced current; IUS -component by soil of the imbalance current

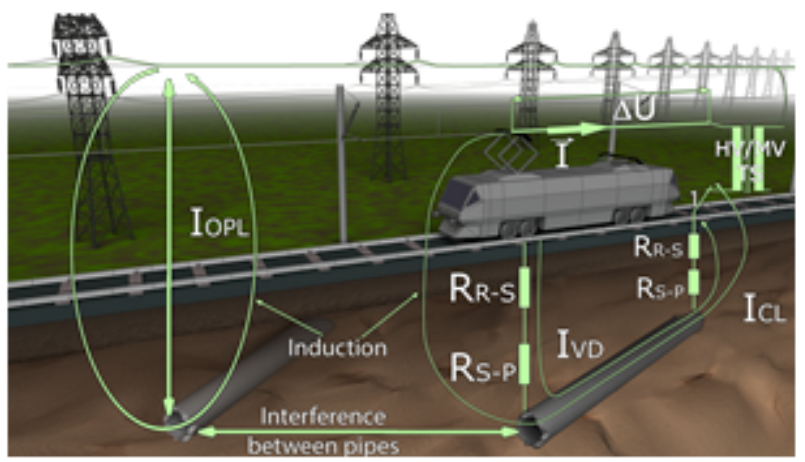

Fig. 2. The sketch of complex AC disturbances coming from overhead power lines and railroads electrified: $R_{R-S}-$ railroad/soil resistance; $R_{\text {s.p }}$-soil/pipeline resistance; I - traction current;

$\Delta \mathrm{U}$ - voltage drop on railroad between connection to the rail 1 and locomotive; HV/MV-TS - high voltage/medium voltage transformer station; $I_{\text {oPL }}$-induced current from overhead power line;

$I_{C L}$-induced current from contact line; $I_{V D}$-stray current due to
In crow ded urban centers, metallic structures operating in electro-conductive environments are interfering with $A C$ stray currents (fig. 1 and fig. 2) overlapping with DC stray currents that originate primarily from urban electric transport railroad.

In figure 3 depicts the DC stray currents under the conditions of crowded urban area with the urban surface electric transport (tram) and underground (metro).

Analyzing figure 3 one may observe that in crowded urban centers the disturbances in DC stray currents are complex with random circulation and affect the urban utilities networks metallic components (underground gas and water pipelines, sewerage, underground power cables etc.), railroad and steel rebar from reinforced concrete structures [1, 22-24].

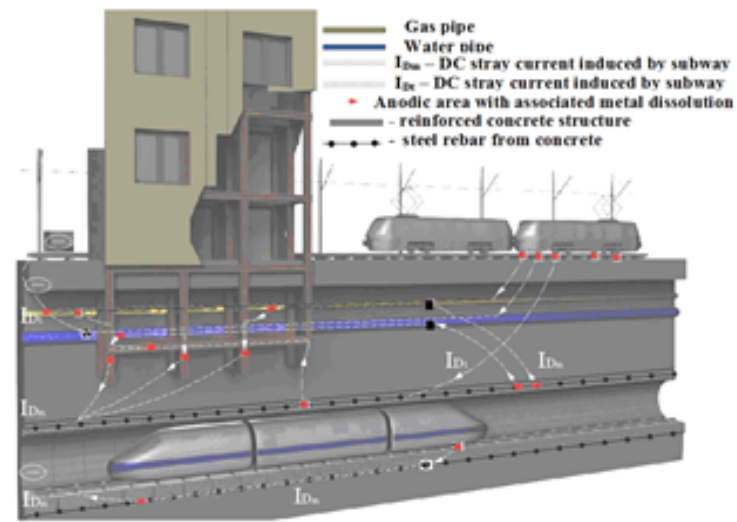

Fig. 3. The sketch of DC stray currents under the conditions of crowded urban centers

Substantial reduction of DC stray currents from tram and subway lines railroads can be achieved by reducing the voltage drop on the railroad and by increasing the insulation level between railroad metallic elements and ground and / or embankment [22-24].

Disturbances through AC stray currents from the power system (fig. 1 and fig. 2) can be reduced by the optimal design of the pipeline and power lines route [25, 26].

\section{Metal / electrolyte equilibrium disruption - accelerated corrosion by stray currents}

At the metal $\mathrm{Me} /$ electrolytic interface, in the absence at external polarization an equilibrium is established (2):

$$
M e \leftrightarrow M e^{z+}+z e^{-}
$$

characterized by the mixed corrosion potential $E_{0}$. The behavior of the metal/electrolyte system is described by the polarization curve (fig. 4) [1].

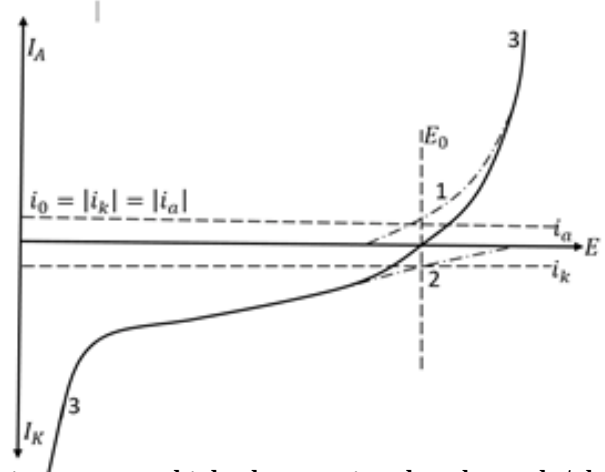

Fig. 4. Polarization curves which characterize the electrode/electrolyte systems: 1 -polarization curve specific to partial anodic process; 2 -polarization curve specific to partial cathodic process; 3 -global polarization curve; $i_{a}$-partial anodic current; $i_{k}$-partial cathodic current; $i_{0}$-the change current specific to the system; $I_{A}$-global anodic current; $I_{K}$ global cathodic current; $\mathrm{E}$-potential of the electrode / electrolyte system; $E_{0}$-equilibrium potential 
According to the polarization curve (fig. 4) [1], the metal / electrolyte system equilibrium is disrupted when the polarization phenomenon occurs.

From the analysis Fig. 4 it's observed that at equilibrium, cathodic partially current is equal to the partially anodic one (3):

$$
i_{0}=\left|i_{k}\right|=\left|i_{a}\right|
$$

where the metal corrosion is determined by the value $i_{0}$ (the functional and morpho-structural metal characteristics theoretical redeposited by $i_{k}$ is completely different from that dissolved by $i_{\text {) }}$.

At cathodic polarization of the metal to the electrolyte the metal dissolution is impossible thermodynamically (cathodic protection by $I_{k}$ ).

At metal anodic polarization $I_{A}$ increase and produces metallic corrosion - the metal amount dissolved Âm during tof the anodic polarization being (4):

$$
\Delta m=\frac{M}{z \cdot F} \int_{t_{0}}^{t} I_{A}(t) d t
$$

where $F$ represents the Faraday number $(\approx 96500$ Coulomb / equivalent grams), $I_{A}$ the anode current, $M$ the atomic mass and $z$ the metal valence.

In figure 5 it is presented the metal / electrolyte system response at $A C$ polarization (a disturbing signal $A C$ overlapped to the polarization curve in fig. 4).

Figure 5 it's show that the metal / electrolyte system response to the $A C$ disturbing signal is an anodically predominantly deformed current $i(t)$ and moves the equilibrium (2) to the right (accelerated corrosion).

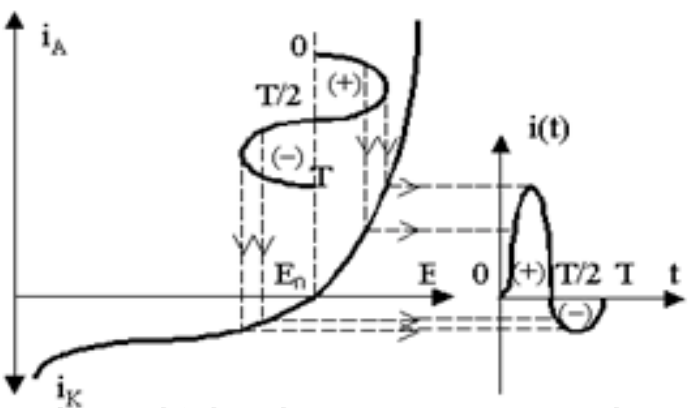

Fig. 5. The metal / electrolyte system response at polarization through an $\mathrm{AC}$ disturbing signal overlapped in $\mathrm{E}_{0}: \mathrm{I}_{\mathrm{A}}$-global anodic current; $I_{K}$-global cathodic current; $E_{0}$-equilibrium potential; $T$-the duration of one period [1]

In the metallic conductors case protected by the cathodic current at the $E_{K}$ potential, the system response to overlapping an $\mathrm{AC}$ disturbing signal is illustrated in figure 6.

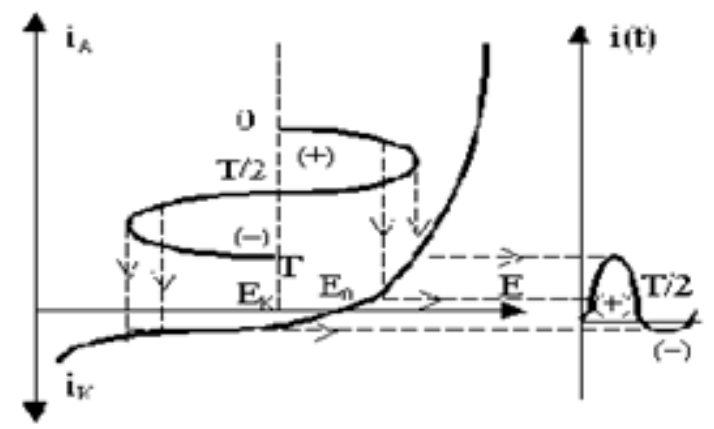

Fig. 6. The influence of a superposed A.C. signal on a cathodic polarised (EK) metal/electrolyte interface [1]
From figure 6 it's noticed that the cathode-protected $\left(E_{K}\right)$ metal / electrolyte system response at AC disturbing signal is an anodically predominantly deformed current $i(t)$ - so even at $E_{k}$ the metal corrosion occurs because the equilibrium (2) moves to the right (accelerated corrosion) the metal mass dissolved being given by (3) the anode component $i(t)$ - confirmed and experimental finding [27].

In practice, metallic structures that operate in electrolytic environments (soil, concrete, etc.) are often exposed to DC stray currents (for e.g. fig. 3) which anodically polarizes $E_{A}$ localized to the metal surface. In these situations overlapping an AC component (fig. 7) creates a corrosion major risk.

In figure 7 it is observed that, in the case of the anodic polarized $\left(E_{\mathrm{A}}\right)$ case metal / electrolyte interface overlapping of an AC disturbing signal, the metal surface is traversed by a deformed alternating current to which even the negative semiperiod is in the anodic field with consequences (often baneful) on corrosion speed.

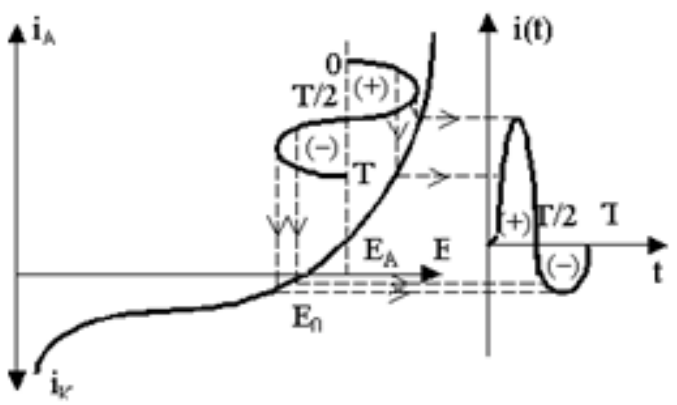

Fig. 7. The influence of a superposed A.C. signal on an anodic polarized $\left(E_{A}\right)$ metal/electrolyte interface [1]

\section{Stress factors of degradations in built up media - synergy effects}

Construction and installation related materials are exposed simultaneous to several stress factors specific to the operating environment. Stress factors may be natural (e.g. salinity, humidity and soil microbiological load, oxygen and atmospheric $\mathrm{CO}_{2}$, visible spectrum radiation especially UV and IR, telluric currents [28] etc.) or anthropogenic origin (aggressive pollutants from the atmosphere, electric stress, etc.). The stress factors action mechanisms influence each other and thus the degradations produced in the builtup media are greater in the simultaneous action case than the sum of the individual degradations produced individually by each factor (effects of synergism [29]).

Thus, the higher salinity and humidity of the soil reduces the metal / soil resistance (fig. 1 and fig. 2), which has as effect increasing the stray currents, the metabolism products of the microorganisms (organic acids) increase the chemical aggressiveness and the electrical conductivity of the environment - depolarizes anodic processes and thus accelerates electrochemical and microbiological corrosion [30-37], $50 \mathrm{~Hz}$ (power frequency) electric field produces major changes in behavior accelerates growth and multiplication of moulds - therefore materials biodegradation enhances [21, 30, 33, 37-47].

\section{$A C$ and DC stray currents effects on some representative constructions}

From the point of view of the degradation mechanisms under the $A C$ and $D C$ stray currents action and the representative stress factors action, there are:

-underground constructions and installations where the stressing factors are humidity, salinity, microbiological flora and morpho-structural soil structure; 


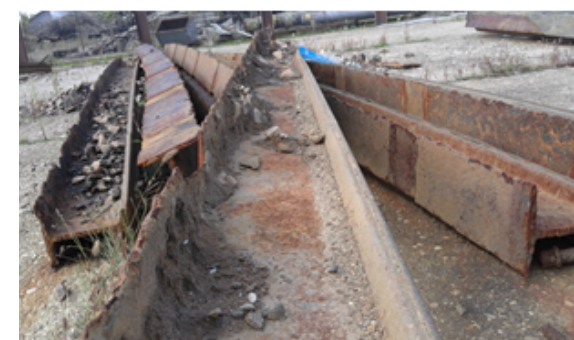

Fig. 8. Degraded tram rails (Oradea city RO)

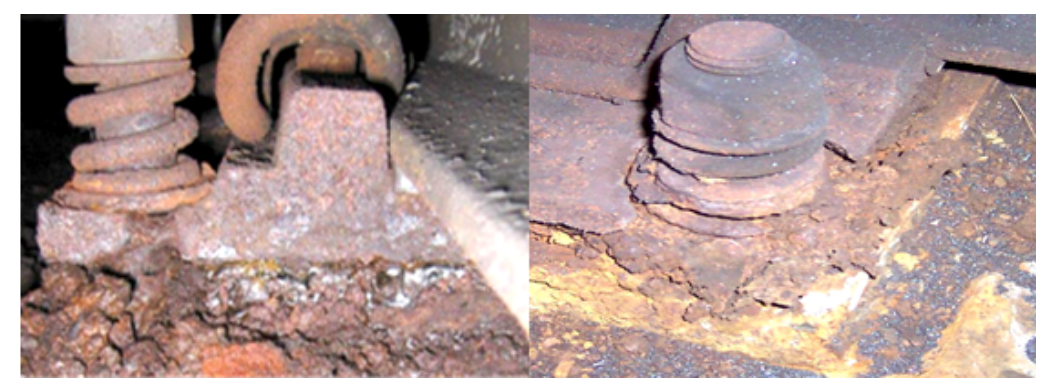

Fig. 9. Massive degradation recorded at Millennium underground (Budapest, HU) after 2 years of operation [23] -overground reinforced concrete structures exposed to $A C$ induced $A C$ stray currents, climatic factors and aggressive agents in the atmosphere.

In practice, at the complex targets with overground and underground portions and / or in contact with ground, develop representative destructions due to $A C$, but especially DC stray currents.

\section{a.Accelerated corrosion of metal structures in contact} with soil

Figure 8 shows the tram rails (DC traction) representative destructions that can be seen along the entire railroad (fig. 3). Similar destructions have also been found in the metallic elements fastening of the rails on embankment in cases when they were not provided with adequate insulation systems (fig. 9).

Figure 8 and figure 9 shows that the anodic polarization of the railroad metallic elements of the urban transport systems with DC traction can lead to massive degradation and endanger the safety in operation. The DC lines coming out of the railroad and entering the ground are taken over by the underground metallic structures (especially pipelines and reinforced concrete structures) from which it exiting in the vicinity of the "-" cable connection point where the dissolution localized by polarization anode of pipelines and reinforced concrete structures disturbed (fig. 3).

It is noted that underground metallic structures disrupted in DC stray currents are simultaneously exposed to AC disturbances according to figure 1 and / or figure 2- situation where the overlapping of the anodic polarization in DC and of the $\mathrm{AC}$ polarization, the destructions (according to figure 7) worsen substantially as illustrated in figure 10 .

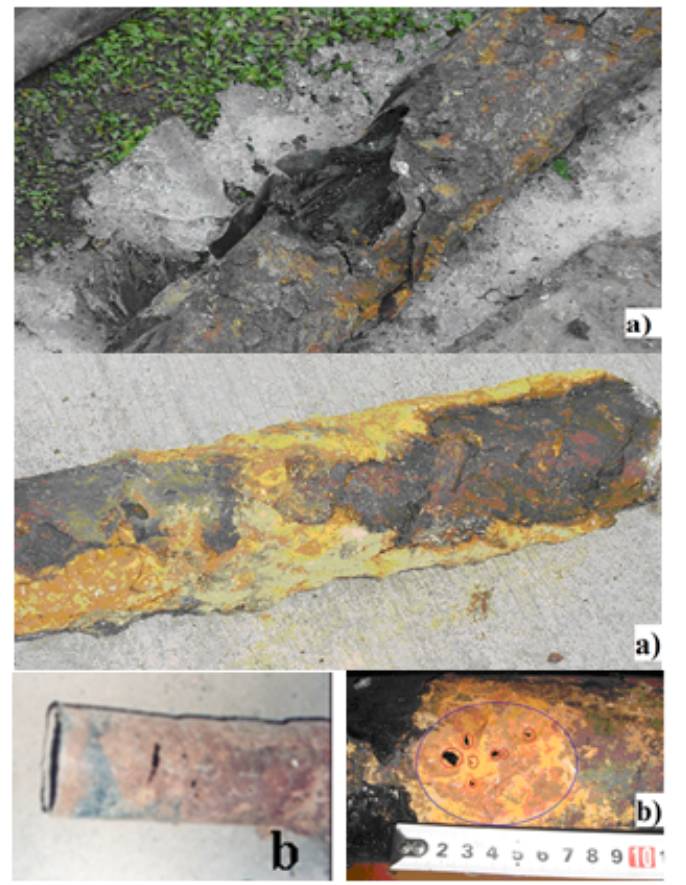

Fig. 10. Corrosion by DC and AC stray currents: - a) - an 3596
On the route of the energy grand highway, the high voltage overhead power line generally has a common route with underground gas and oil pipelines, where the disturbances caused by induced AC signals at power frequency are significant, which required the evaluation and study of the AC polarization effects of pipelines [1, 27, 48-54], elaboration of the method for calculating disturbances [13-17, 55-59] and for the corrosion damage prevention [60-65]. Figure11. shows the destructions by corrosion of the earthing sockets (made from galvanized steel profiles) polarized in AC through umbalanced currents of tree phase power system [66-68].

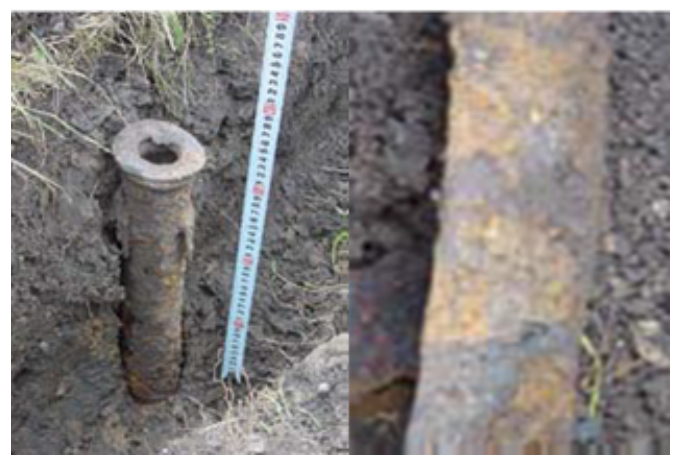

Fig. 11. Corrosion degradation due to $\mathrm{AC}$ polarization of $\mathrm{Zn}$ covered steel earthing grids from the tree phase power system

Figure 11 shows that earthing grids corrosion degradation is significant (especially those in urban area with DC tracted trams [66,67]), which leads to significant increase in earthing resistance [69-71]. From e.g. (3) it follows that the decrease during exploitation of the corrosion degradations illustrated in figure 8 - fig. 11 is possible by decreasing intensity of $A C$ and $D C$ stray currents what is possible (in the context of fig. 1, fig. 2 and fig. 3 ) by decreasing unbalanced currents from power systems and / or a voltage drop on the railroads (optimized design and exploitation), respectively by optimizing routes for disturbances reduction by induction [13, 14, 17]. It is also important to ensure an adequate and reliable isolation system between rails and embankment / soil [1].

\section{b. Reinforced concrete structures degradation}

In the reinforced concrete structures case, $A C$ and $D C$ stray currents cause both steel bars corrosion and concrete degradation [24, 72-79]. At the concrete anodic polarization, the cement oxidation components dissolve and the concrete is leached ( $\mathrm{pH}$ decreases [77]) which leads to the concrete degradation and to the steel bars accelerated corrosion [72]. In the concrete excessive cathodic polarization, the oxidation degree of oxide components in the cement is reduced, which leads to the contraction and the concrete cracking [72].

Corrosion products of steel bars, generate mechanical stress (up to $500 \mathrm{~kg} / \mathrm{cm}^{2}$ ) [82] leading to major physical degradation of the concrete. In these conditions, due to stress factors and $A C$ and DC stray current and multiple 
synergic effects, the underground reinforced concrete structures degradation [24,78,79,81,83-85] and / or overhead $[76,86]$ are significant. Figure 12 presents degradation representative images of a metro tunnel under the DC stray currents synergic action, of microbiological factors and hydrostatic water pressure.
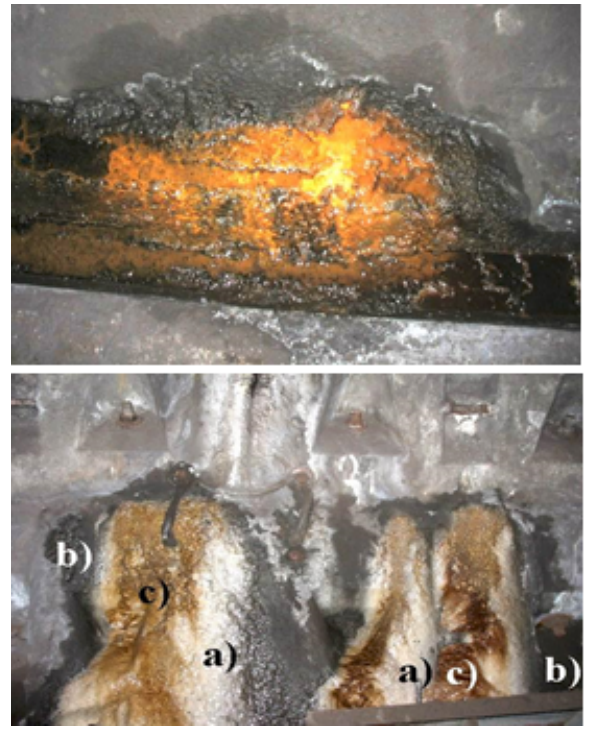

Fig. 12. Steel corrosion and reinforced concrete degradation in a metro tunnel: a) leaching of calcium; b) microbial colonies (bacteria and fungi); c) - iron dissolving from steel rebar

Figure 13 presents reinforced concrete pillars of power lines due to the induced AC stray currents synergic action, climatic weather, microbiological factors and aggressive compounds in the atmosphere $\left(\mathrm{CO}_{2}, \mathrm{SO}_{2}, \mathrm{NO}_{x}\right.$ etc. $)$.

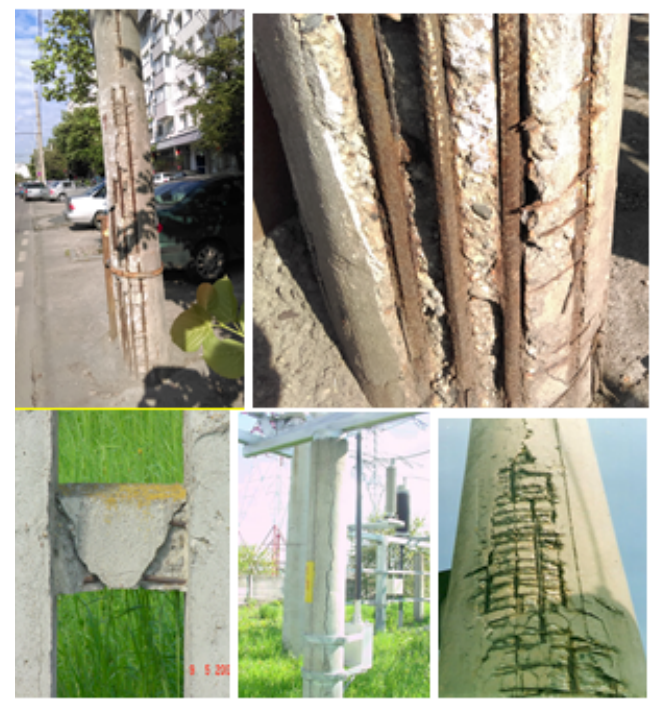

Fig. 13. Degradation of some reinforced concrete pillars of power lines

Figure 14 the degradation of a road bridge due to the induced AC stray currents synergic action from the railroad contact line $(28 \mathrm{kV})$, climatic weather, microbiological factors and aggressive compounds in the atmosphere $\left(\mathrm{CO}_{2}\right.$, $\mathrm{SO}_{2}, \mathrm{NO}_{\mathrm{x}}$ etc.) is presented.
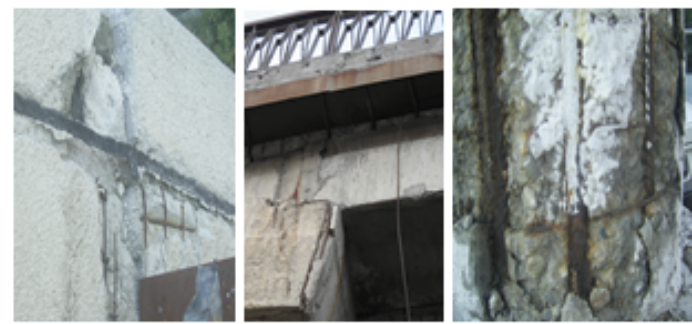

Fig. 14. The degradation of a road bridge (passage over an electrified railrods)
To increase the exploitation time of the structures in figure 12 , the corrosion rate may be decrease (3) by a voltage reduction and providing an adequate and reliable isolation system between the rails and the embankment / soil.

Figure 1 and figure 3 show that $A C$ and DC stray currents act on the output and inlet areas (in the AC case) from the metal to the electrolytic medium of the current lines.

In order to reduce the disturbed surfaces areas, to reinforced concrete structures exposed to $A C$ and / or DC ditsy currents disruptions it is necessary to ensure the electrical continuity between steel rebar that involves fastening stirrup by welding (not by binding as seen in fig. 13 and fig. 14 - fully corroded stirrups).

\section{c.Underground power cables degradation}

Underground power cables degradation is the result of some successive complex processes, due to the synergic action of several stress factors (electrical, thermal, chemical and microbiological soil aggression etc.) $[29,43$, 45-47, 87, 88].

The first stage (determinant of the global process) consists in the degradation of the protective polymer coating (fig. 15) under influence of the chemical and microbiological soil stress. The protective layer polymer becomes porous, permeable to soil aggressive agents (humidity, salinity, oxygen, etc.) that penetrate the metal screen and thus makes possible the metal corrosion. Corrosion products formed and the moisture, penetrate to the insulation surface (usually cross-linked polyethylene) form water treeing which, under electric stress act (operating voltage), initiates and develops electrical treeing that penetrate into the insulation volume and form conductive channels.

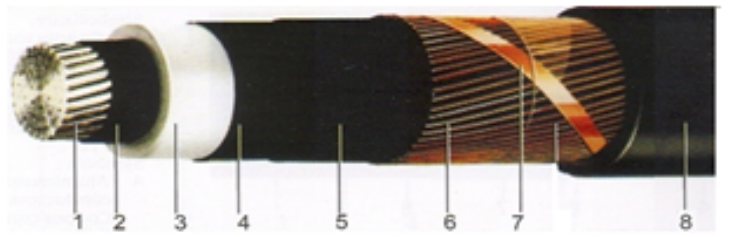

Fig. 1b. Mealum ana hıgh voltage cables constructıon: 1 - Alumınum or copper conductor; 2 - Inside semiconductor layer; 3 - insulation

(cross-linked polyethylene); 4 -External semiconductor layer;

5 - Semiconductor tape; 6, 7 - metallic shielding; 8 -protective polymer coating (polymeric jacket)

Thus, the cable insulation resistance decreases significantly (ageing) and in extreme situations, under the operating voltage, the cable breaks down through puncture (fig. 16).
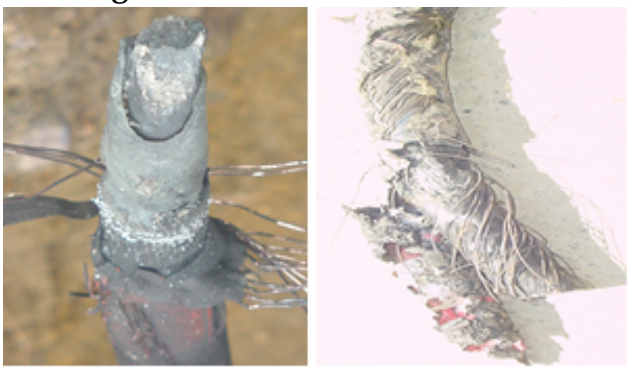

Fig. 16. Medium voltage power cable degraded and broken by puncture

The laboratory studies [43, 89], confirmed by field investigations / analyzes $[45,46]$, show that in the degradation process the polymeric jacketpermeability, the microbiological soil flora, especially filamentous molds, have a determining role. 
From figure 17 it's found that the resistance at molds action of the polymer used in the medium voltage cables manufacture is relatively limited [89].

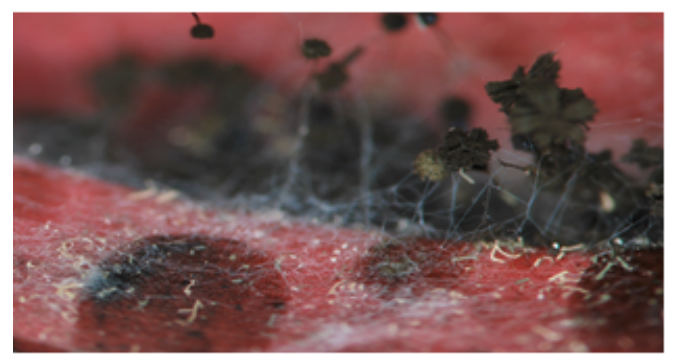

Fig. 17. Mold colonies (Aspergillus niger and Aspergillus terreus) grown on a polymeric jacket sample (A2xSrY type cable) [89].

In Ffigure 15 it is observed that during the operation between the metallic shielding of power cables and soil, on the polymeric jacket an AC disturbance occurs at the industrial frequency, both by induction and by the operating voltage division on the capacitive divisor consisting of conductor capacity / metallic shielding and metallic shielding / soil.

Under these conditions, the surface in contact with the polymeric jacket soil is exposed to an AC electric field. The $50 \mathrm{~Hz}$ electric field modifies the microorganisms metabolism [37-39] and accelerates their growth and multiplication [41], which leads to the bio-corrosion processes integration [44] and polymers biodegradation $[18,42]$.

A protective process $[90,91]$ with efficiency demonstrated by field monitoring [45-47] has been developed to prevent aging processes of underground power cables from corrosion products of metallic shielding formed by the polymeric jacket degradation.

\section{Conclusions}

As technological developments are continuously growing, the electricity production and consumption are constantly increasing, so the electromagnetic pollution sources of the environment are becoming more and more diversified and intensified.

In built up media (complex built environment) the materials are exposed simultaneously to a physical, chemical and microbiological stress factors series that act synergistically with disruptive electromagnetic fields and cause material degradation - with consequences on the durability and safety in operation of buildings and installations. The most common disruptions fields generators sources (stray currents generators) on built of media are transport systems on rails with traction in DC or AC transmissions with various operating voltage and frequency [92], medium and high voltage overhead power lines and the unbalanced currents from three-phase system [1]. Generated stray currents cause damage to both metallic structures / elements and reinforced concrete of the generators sources (railrods, power installations) and neighboring constructions and installations (with other administrations) with negative environmental implications. With a view to sustainable development, in order to increase the buildings and installations durability and safety, to prevent the destruction caused by $A C$ and DC stray currents, it is considered appropriate to develop and implement effective preventive and protective methods.

This is only possible through inter - and transdisciplinary knowledge (mechanical, electrical, chemical engineering, materials science, biology, environment, etc.).

It is considered necessary to reconsider education systems with an emphasis on inter- and transdisciplinary knowledge and sustained environmental education [9395] and to develop and implement appropriate technical regulations [96] environment/ health issues, noteconomic interests).

Acknowledgment: This work was financially supported by the UEFISCDI of Romania, under the scientific Program NUCLEU 2016 2017, contractPN 16110211 /2016 and the H2020 program, Project ID: 766180/ 2017-2021, acronym INTERACT H2020-MSCA-ITN - 2017, https:/ /cordis.europa.eu/project/rcn/212860_en.html

\section{References}

1. LINGVAY, I., VOINA, A., LINGVAY, C., MATEESCU, C., Revue Roumaine des Sciences Techniques série Électrotechnique et Énergétique, vol. 53 (2bis), 2008, pp. 95-112.

2. ZAKOWSKI, K., DAROWICKI, K., Polish Journal of Environmental Studies, vol. 8 (4), 1999, pp. 209-212.

3. ISOC, D., IGNAT-COMAN, A., J OLDIa , A., AIP Conference Proceedings, 2008. p. 1019, pp. 383-388.

4. IGNAT-COMAN, A., ISOC, D., JOLDIS, A., GAZIUC, I., IEEE International Conference on Automation, Quality and Testing, Robotics, AQTR 2008 - THETA 16th Edition - Proceedings 1.4588730, 2008, pp. 178-183.

5. ISOC, G., ISOC, T., ISOC, D., Studies in Computational Intelligence, vol. 486, 2014, pp. 53-64.

6. ISOC, D., Advances in Intelligent Systems and Computing, vol. 633, 2018, pp. 18-33.

7. ISOC, D., Advances in Intelligent Systems and Computing, vol. 633, 2018, pp. 34-46.

8. NEVILLE, A.M., Pitman Publishing Ltd.1975, pp. 370-374.

9. MATEI, G., LINGVAY, D., SPAFIU, P.C., TUDOSIE, L.M., Electrotehnica, Electronica, Automatica (EEA), vol. 64 (4), 2016, pp. 52-58.

10. CHICCO, G., POSTOLACHE, P., TOADER, C., Electric Power Systems Research, Vol. 81 (7), 2011, pp.1541-1549.

11. SPAFIU, P.C., LINGVAY, D., MATEI, G., Electrotehnica, Electronica, Automatica (EEA), vol. 65 (1), 2017, pp. 24-30.

12. MARIN, D., MITULEP, A., LINGVAY, M., Electrotehnica, Electronica, Automatica (EEA), vol. 61 (2), 2013, pp. 58-64.

13. NASSEREDDINE, M., RIZK, J., NAGRIAL, M., HELLANY, A., MICU, D.D., Proceedings of the Universities Power Engineering Conference, 2015, p. 7339854.

14. CZUMBIL, L., MICU, D.D., STET, D., CECLAN, A., International Symposium on Fundamentals of Electrical Engineering, ISFEE 2016, p. 7803231 .

15. STET, D., MICU, D.D., CZUMBIL, L., MANEA, B., EPE 2014 Proceedings of the 2014 International Conference and Exposition on Electrical and Power Engineering, p. 6969903, 2014, pp. 231-236.

16. MICU, D.D., CHRISTOFORIDIS, G.C., CZUMBIL, L., Electric Power Systems Research, vol. 103, 2013, pp. 1-8.

17. STET, D., MICU, D.D., AVRAM, C., DARABANT, L., 7th International Symposium on Advanced Topics in Electrical Engineering, ATEE 2011, p. 5952251.

18. BORS, A.M., BUTOI, N., CARAMITU, A.R., MARINESCU, V., LINGVAY, I., Mat. Plast., 54, no. 3, 2017, p. 447-452.

19. OPRINA, G., RADERMACHER, L., LINGVAY, D., MARIN, D., VOINA, A., MITREA, S., Rev. Chim. (Bucharest), 68, no. 3, 2017, p. 581-585.

20. NITA, P., LINGVAY, M., SZATMÁRI, I., LINGVAY, I., Electrotehnica, Electronica, Automatica (EEA), vol. 61 (3), 2013, pp. 40-45.

21. VOINA, A., NITA, P., LUCHIAN, A.-M., LINGVAY, D., BUTOI, N., BORS, A.M., LINGVAY, I., Electrotehnica, Electronica, Automatica (EEA), vol. 65 (2), 2017, p. 60-65.

22. LINGVAY, J., Korróziós figyelõ, 44 (6), 2004, pp. 187-194.

23. PUKLUS, Z., LINGVAY, J., HODOSSY L., Korrozios figyelo, 45 (2), 2005, p. 43.

24. LINGVAY, I., GABOR, M., LINGVAY, C., Rev. Chim. (Bucharest), 57, no. 2, 2006, p. 180-183.

25. *** CIGRE Working Group 36.02. - Guide Concerning Influence of High Voltage AC Power Systems on Metallic Pipelines. Canada, 1995 26. CZUMBIL, L., MICU, D.D., MUNTEANU, C., STET, D., TOMOIOAGA, B., Proceedings of the Universities Power Engineering Conference, 2015, p. 7339841.

27. DING, Q., FAN, Y., International Journal of Corrosion, vol. 2016, 2016. doi.org/10.1155/2016/5615392, Article ID 5615392 (8 pages).

28. VILJANEN, A., Geophysical, vol. 25 (1-2), 1989, pp. 135-159. 
29. CIOGESCU, O., TUDOSIE, L., LINGVAY, C., VLADOI, C., LINGVAY, I., Electrotehnica, Electronica, Automatica (EEA), vol. 60 (3), 2012, pp. 50-58.

30. LINGVAY, J., GROZA, C., LINGVAY, C., CSUZI, I., Korrozios Figyelo, 49 (3), 2009, pp. 31-38.

31. LINGVAY, J., SZATMARI, I., PRIOTEASA, P., LINGVAY, M., TUDOSIE, L.M., Korrozios figyelo, vol. 54 (1), 2014, pp. 15-21.

32. RADU, E., PATROI, D., OPRINA, G., VOINA, A., LINGVAY, I., Rev. Chim. (Bucharest), 67, no. 10, 2016, p. 1973-1978.

33. RADU, E., MITREA, S., PATROI, D., VOINA, A., MOSCALIUC, $H$., LINGVAY, I., IEEExplore - DEMISEE 2016, p. 38-43.

34. LINGVAY J ., RADU E., MITREA S., LINGVAY M., UDREA O., SZATMÁRI I., Korrozios figyelo, vol. LIV (2), 2014, pp. 40-46.

35. PRIOTEASA, P., LINGVAY, M., SZATMÁRI, I., BURUNPEA, N., LINGVAY, I., Electrotehnica, Electronica, Automatica (EEA), vol. 62 (2), 2014, pp. 60-65.

36. LINGVAY, I., RUS, G., BURUNTEA, N., UPB Sci. Bull, Series B, vol. 63 (3), 2001, pp. 29-36.

37. LINGVAY, M., STANCU, C., SZATMÁRI, I., LINGVAY, I., Electrotehnica, Electronica, Automatica (EEA), vol. 61 (1), 2013. pp. $43-47$.

38. GOLTSOV, A.N., Bioelectrochem. Bioenerg., vol. 48, 1999, pp. 311-316.

39. STANCU, C., LINGVAY, M., SZATMARI, I., LINGVAY, I., 8th International Symposium on Advanced Topics in Electrical Engineering, Bucharest, Romania, May 23-25, 2013, pp. 1-4.

40. SANDU, D., LINGVAY, I., LANYI, S., MICU, D.D., POPESCU, C.L., BREM, J., BENCZE, L.C., PAIZS, C., Studia Universitatis Babes-Bolyai, Chemia, vol. LIV (4), 2009, pp. 195-201.

41. RADU, E., LIPCINSKI, D., TANASE, N., LINGVAY, I., Electrotehnica, Electronica, Automatizari (EEA), vol. 63 (3), 2015, p. 68-74.

42. CARAMITU, A., BUTOI, N., RUS, T., LUCHIAN, A.M. MITREA, S., Mat. Plast., 54, no.2, 2017, p. 331-337.

43. LINGVAY, I., OLLERER, K., LINGVAY, C., HOMAN, C., CIOGESCU,

O., Rev. Chim. (Bucharest), 58, no. 7, 2007, p. 624-627.

44. LINGVAY, I., RUS, G., STOIAN, F., LINGVAY, C., UPB Sci. Bull, Series B, vol. 63 (3), 2001, pp. 263-270.

45. SZATMARI, I., LINGVAY, M., TUDOSIE, L., COJOCARU, A., LINGVAY, I., Rev. Chim. (Bucharest), 66, no. 3, 2015, p. 304-311.

46. LINGVAY, J., SZATMÁRI, I., LINGVAY, M., TUDOSIE, L., Korrozios figyelo, vol. 53 (3), 2013, pp. 71-80.

47. SZATMARI, I., LINGVAY, M., VLADOI, C., LINGVAY, I., Electrotehnica, Electronica, Automatica (EEA), vol. 61 (4), 2013, pp. 48-55.

48. BABAGHAYOU, F., ZEGNINI, B., SEGHIER, T., Electrotehnica, Electronica, Automatica (EEA), vol. 65 (4), 2017, pp. 108-116.

49. ORMELLESE, M., GOIDANICH, S., LAZZARI, L., Corrosion Science, vol. 52, 2009, pp. 916-922.

50. WANG, X.H., YANG, G., HUANG H., CHEN, Z., WANG, L., Applied Mechanics and Materials, Vols. 263-266, 2012, pp. 448-451.

51. GUO, Y.-B., LIU, C., WANG, D.-G., LIU, S.-H., Petroleum Science, vol. 12 (2), 2015, pp. 316-324.

52. ZHU, Q., CAO, A., WANG, Z., SONG, J, CHEN, S., Anti-Corrosion Methods and Materials, vol. 58 (5), 2011, pp. 234-237.

53. CUI, G., LI, Z.-L., YANG, C., WANG, M., Petroleum Science, vol. 13

(1), 2016, pp. 135-145.

54. SHABANGU, T.H., SHRIVASTAVA, P., ABE, B.T., ADEDEJI, K.B., OLUBAMBI, P.A., IEEE Africon 2017, Proceedings, doi: 10.1109/ AFRCON.2017.8095549

55. DJEKIDEL, R., MAHI. D., Przegl'1d Elektrotechniczny, vol. 90 (9), 2014, p. 151.

56. MICU, D.D., LINGVAY, I., LINGVAY, C., CRET, L., SIMION, E., Revue Roumaine des Sciences Techniques serie Électrotechnique et Énergetique, vol. 54 (2), 2009, pp. 175-184.

57. PONNLE, A.A., ADEDEJI, K.B., ABE, B.T., JIMOH, A.A., Progress in Electromagnetics Research B, vol. 69, 2016, pp. 75-86.

58. QI, L., YUAN, H., WU, Y., CUI, X., Electric Power Systems Research, vol. 94, 2013, pp. 54-63.

59. SZTAFROWSKI, D., GUMIELA, J., WROBLEWSKI, Z., Przegl ${ }^{1} \mathrm{~d}$ Elektrotechniczny, vol. 93 (3), 2017, pp. 228-231.

60. LINGVAY, I., CALIN, C., STOIAN, F., BABUTANU, C., LINGVAY, C., SECRETEANU, N., Revue Roumaine de Chimie, vol. 46 (2), 2001, pp. 85-90.

61. LINGVAY, J., Korrozios Figyelo, vol. 44 (2), 2004, pp. 49-55.
62. LINGVAY, C., LINGVAY I., Patent RO 122001 B1 Device for electroprotection and controlled corrosion protection of underground metallic pipes exposed to alternating current polarization, 2006.

63. LINGVAY I., LINGVAY C., Patent RO 121754 B1 Double high-power transient overvoltage limiting device and manufacturing process, 2006. 64. LINGVAY, I., LINGVAY, C., STOIAN, F., BABUTANU, C.A., Patent RO 119399, Device for electroprotection of metalic structures, 2004.

65. LINGVAY, I., LINGVAY, C., Patent RO 113778, Method and solid state device for electroprotection of metalic structures, 1998.

66. LINGVAY, I., HOMAN, C., LINGVAY, C., Rev. Chim. (Bucharest), 58, no. 11, 2007, p. 1051-1054.

67. LINGVAY, J., LINGVAY, C., Korrozios figyelo, 46 (1), 2007, pp. 8-12. 68. KOVACS J., LINGVAY J., Korrozios figyelo, 44 (4), 2004, pp. 134136.

69. LADANYI, J., Electrotehnicã, Electronica, Automatizari (EEA), vol. 58 (2), 2010, pp. 35-38.

70. SMOHAI, B., LADANYI, J ., Electrotehnica, Electronica, Automatizari (EEA), vol. 62 (2), 2014, pp. 85-92.

71. SMOHAI, B., LADANYI, ., Electrotehnica, Electronica, Automatizari (EEA), vol. 63 (3), 2015, pp. 60-67.

72. LINGVAY, C., COJOCARU, A., VISAN, T., LINGVAY, I., U.P.B. Sci. Bull., Series B, vol. 73 (4), 2011, pp. 143-152.

73. SUSANTO A., KOLEVA D.A., VAN BREUGEL K., VAN BEEK K., J ournal of Advanced Concrete Technology, doi:10.3151/jact.15.244, vol. 15 (6), 2017, pp. 244-268.

74. SUSANTO, A., KOLEVA, D.A., COPUROGLU, O., VAN BEEK, K., VAN BREUGEL, K., Journal of Advanced Concrete Technology, vol. 11 (4), 2013, pp. 119-134.

75. CHEN, M., WANG, K., WU, Q., QIN, Z., Applied Mechanic and Materials, Vols. 166-169, 2012, pp. 1987-1993.

76. LINGVAY, I., LINGVAY, C., HOMAN, C., CIOGESCU, O., Rev. Chim. (Bucharest), 57, no. 12, 2006, p. 1279-1282.

77. LINGVAY, I., GOMBOS, S., LINGVAY, C., KOVACS, J., VOINITCHI C.-

D., Rev. Chim. (Bucharest), 57, no. 5, 2006, p. 498-500.

78. YANG, S., YANG, X., Front. Archit. Civil Eng. China, vol. 2 (3), 2008, pp. 246-252.

79. LINGVAY I., GABOR M., VOINITCHI C.-D., LINGVAY C., Rev. Chim. (Bucharest), 57, no. 4, 2006, p. 378-382.

80. BERTOLINI, L., CARSANA, M., PEDEFERRI, P., Corros. Sci., vol. 49 (3), 2007, pp.1056-1068.

81. LINGVAY I., Rev. Chim. (Bucharest), 57, no. 3, 2006, p. 261-265.

82. PILTNER, R., MONTEIRO, P.J.M., Cement and Concrete Research, vol. 30, Issue 6, J une 2000, pp. 843-848.

83. LINGVAY, J., KOVACS, J., Korrozios figyelo, vol. 45 (3), 2005, pp. 88-91.

84. LINGVAY J., Korrozios figyelo, vol. 44 (6), 2004, pp. 187-194.

85. LINGVAY, J., LINGVAY, C., BALAN-KOVACS J., GOMBOS S., Korrozios figyelo, vol. 45 (6), 2005, pp. 200-204.

86. RADERMACHER, L., LIPCINSKI, D., BUTOI, N., LINGVAY, D., CARAMITU, A., MARIN, D., Electrotehnica, Electronica, Automatizari (EEA), vol. 65 (2), 2017, pp. 140-146.

87. LINGVAY, J., LINGVAY, C., OLLERER, K., HOMAN, C., TANKO, I., CIOGESCU, O., Korrozios figyelo, vol. 46 (4), 2006, pp. 102-105.

88. LINGVAY I., LINGVAY C., CIOGESCU O., HOMAN C., Rev. Chim. (Bucharest), 58, no. 1, 2007, pp. 44-47.

89. LINGVAY, J., GROZA, C., LINGVAY, C., CSUZI, I., Korrozios figyelo, vol. 49 (3), 2009, pp. 31-37.

90. LINGVAY, I., LINGVAY, C., Patent RO 113502, Method and device for increasing the underground electrical cables maintenance, 1998.

91. LINGVAY, J., KOVÁCS, J., Korrozios figyelo, vol. 44 (3), 2004, pp. 82-89.

92. CHEN, Z., KOLEVA, D., VAN BREUGEL, K., Corros Rev., vol. 35 (6), 2017, https://doi.org/10.1515/corrrev-2017-0009

93. OLLERER K., Environmental education - Between necessity and opportunity, Calitatea Vieii, vol. 23 (1), 2012, pp. 25-44.

94. BOGNER, F.X., Journal of Environmental Education, vol. 29 (4), 1998, pp. 17-29.

95. OLLERER K., J ournal of Integrative Environmental Sciences, vol. 12 (3), 2015, pp. 205-216.

96. ROWLEY, J., Revue Roumaine des Sciences Techniques série Électrotechnique et Energetique, Tome 53 (2bis), 2008, pp. 65-78. 